\title{
Lamang tapai: the ancient Malay food in Minangkabau tradition
}

\author{
Tania YovaniiD
}

\begin{abstract}
Lamang tapai is a traditional food which consists of lemang and tapai that are used in various traditional ceremonies of Minangkabau people, mainly in West Sumatra. However, lemang and tapai are also known as traditional foods of other tribes or regions in Southeast Asia, and their cooking method is still very ancient and depends on the state of nature. These two points show that lemang and tapai can be used as historical evidence for ancient human life in Southeast Asia, which is Proto-Malay and Deutero-Malay. Minang people believe that cooking technique of lemang was first introduced by Sheikh Burhanuddin. Lemang is incomplete if it is not eaten together with tapai, so they are likened to a man and a woman by Minang people. Lemang itself describes the togetherness of Minang people because its making process is always done together. There are several taboos that must be obeyed in making lemang and tapai. Lamang tapai are also used as gifts when visiting other people's homes, for example, when visiting in-laws or manjapuik marapulai ceremony. However, there is no symbolic meaning behind the obligatory existence of lamang tapai at traditional ceremonies. On the other hand, lemang and tapai are famous for their unique taste produced by the chemical components in their ingredients. In this article, the origin of lemang and tapai, the philosophy and presentation of lemang in the traditions of the Minangkabau people, and the flavor features of lemang and tapai from a scientific perspective are discussed.
\end{abstract}

Keywords: Lemang, Lamang, Minangkabau, Tapai ketan, Tape ketan

\section{Introduction}

A traditional food is an identity of a tribe or nation because of its relation to the culture of the people in that nation or tribe. However, some traditional foods used in traditional ceremonies of the community in a region or tribe are also used in traditional ceremonies of the community in other regions or tribes. This kind of food can be historical evidence about the origin of the population in a region or the cultural influence of other nations on a nation. Lemang and tapai are two examples of typical foods in Indonesia which are also known as traditional foods of other countries.

Lemang is a food made from white glutinous rice mixed with coconut milk in a bamboo in which its inner part has been coated with banana leaf and cooked using open fire. This bamboo rice can be found in Indonesia, Malaysia [1], Brunei Darussalam [2], and Thailand [3]. It is generally called lemang by Indonesians [4], Malaysians

Correspondence: tanyovani111@gmail.com

Nutrition and Food Technology Department, Faculty of Life Science, Surya University, Tangerang, Indonesia
[1], and Bruneians [2]; as khao lham in Thailand [3]; as lomang by Batak people; and as lamang by the Minangkabau people [4].

People in each region have their own ways to enjoy lemang. Some people consume lemang with salty foods such as rendang and eggs, and the others consume it together with sweet complementary ingredients such as jam, liquid brown sugar, and grated coconut. However, in Minangkabau, lemang is identically served with tapai (or tape). These two foods are often considered as one food called lamang tapai [5]. Minangkabau or commonly called as Minang is an ethnic group that dominate the population in West Sumatra, Indonesia (Fig. 1).

There are two kinds of tapai, namely tapai singkong (also known as peuyeum) and tapai ketan (also known as tapai pulut). Tapai which is served with lemang is tapai ketan, the black sticky rice which is fermented by ragi. Not only known in Indonesia and Malaysia, tapai ketan is also known in Thailand as khaomak and in China as lao-chao [6, 7].

(c) The Author(s). 2019 Open Access This article is distributed under the terms of the Creative Commons Attribution 4.0 International License (http://creativecommons.org/licenses/by/4.0/), which permits unrestricted use, distribution, and reproduction in any medium, provided you give appropriate credit to the original author(s) and the source, provide a link to the Creative Commons license, and indicate if changes were made. The Creative Commons Public Domain Dedication waiver (http://creativecommons.org/publicdomain/zero/1.0/) applies to the data made available in this article, unless otherwise stated. 


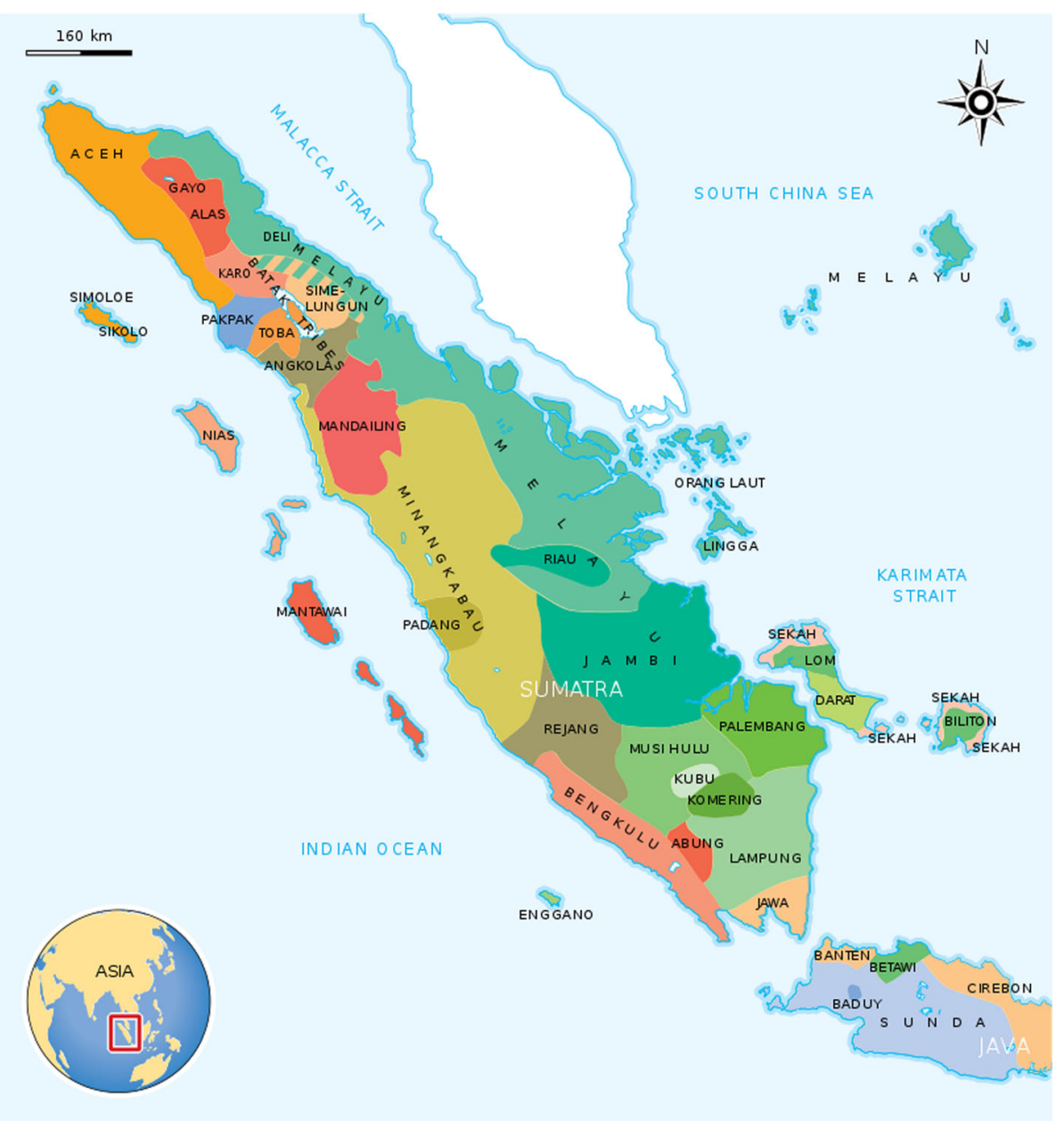

Fig. 1 The map of ethnic groups in Sumatra. Minangkabau region is marked in light and dark olive on the map. This map shows that West Sumatra with Padang as the capital city is the center of the Minangkabau tribe. Source: Based on "Peta Suku Bangsa di Indonesia" at National Museum of Indonesia, Jakarta in wikipedia.org, 2010

Although lemang and tapai can be found in various other regions, lemang which is consumed along with tapai is well-known to be found in the Minangkabau highlands. One of them is Batusangkar Market in Tanah Datar District. The savory and sour taste of lamang tapai is believed to warm the human body in the highlands [8].

Most of the area of West Sumatra Province as the homeland for Minangkabau people is highland. In this highland, there are three well-known areas called Luhak nan Tigo, which roughly means "the three mountains": Luhak Agam, Luhak Payakumbuh or 50 Koto (50 cities), and Luhak Tanah Datar. These areas are the origin places of the development of the Minangkabau ethnic group [9]. Moreover, the Minangkabau people are very famous for their wandering or going overseas culture. They succeeded in forming populations in other parts of Indonesia (Pekanbaru, Jakarta, Bandung, Medan, Batam, Surabaya, Palembang), Malaysia (Negeri Sembilan, Kuala Lumpur,
Malacca, Penang), Singapore, and Brunei Darussalam [10]. These are the reasons behind the recognition of lamang tapai as a typical food of Minangkabau that can be found in various other regions.

Lamang tapai is widely consumed as a break-the-fast menu in the month of Ramadan and as a dish at various traditional ceremonies and Islamic holidays, especially in Minangkabau. According to Bakry, the culturalist, Minang people feel strange if there is no lemang in an event held by people from their ethnic, because presenting lemang at each event has become an inherent habit for them. There is also a tradition called malamang which is routinely carried out by Minang community before important celebrations are held. In this tradition, they work together to make lemang: prepare ingredients and equipment and burn lemang [11].

Lemang has unique and soft fragrant aroma due to its ingredients and traditional cooking process. Traditional method of cooking lemang which uses bamboo as 
cooking equipment shows that lemang is the evidence of ancient human life that was very dependent on nature and did not know metal cookware yet. On the top of that, there is also a folklore that is believed by Minang people as an explanation of how they knew the making process of lemang for the first time, which will be discussed in this review. Specific bamboo species for making lemang itself and two other ingredients such as coconut milk and banana leaves cause lemang to have a pleasant aroma. On the other hand, tapai as a complement to lamang has the aroma of alcohol and sweetand-sour taste due to fermentation process that has been known since ancient times.

Previous review made by Wahyudi et al. (2017) only describes the culture of lemang in general in several regions of Indonesia. There has been no review about the origin of lemang and tapai, and the philosophy and presentation of lamang tapai in Minangkabau tradition specifically. Both lemang and tapai can be historical evidence of the origin of the Minangkabau population and their tradition thanks to the popularity of lamang tapai as a traditional food of Minangkabau. Moreover, the specialty of lemang and tapai as traditional food which came from their unique aroma and taste can be explained scientifically. Therefore, this review will describe the origin of lemang and tapai, the philosophy and presentation of lamang tapai in the traditions of the Minangkabau people, and the flavor features of lemang and tapai from scientific perspective.

\section{The origin of lemang and tapai in Minangkabau Lemang}

Asnan, a professor of history, said that the technique of cooking rice using bamboo which is the basis for the creation of lemang is thought to have been known by the Proto-Malay or Deutero-Malay people, who were the ancestors of Indonesian people because it was known by various ethnic groups in Indonesia, especially in the West. This statement was supported by Wojowasito (1970) who stated that the Proto-Malay nation had been able to use rice, sugar, coconuts, bamboo, bananas, and rattan from its origin.

Proto-Malay was a nation that came to the Indonesian mainland from Yunnan in South China around 3000 BC [12]. Yunnan is known as the region with the highest number of bamboo species and the most abundant natural bamboo forest in the world [13]. The time of the arrival of the Proto-Malay nation in Indonesia was the Neolithic era, when the people had become farmers and ranchers with permanent dwellings such as houses or huts, could rub tools from stone until smooth, make good pots, and also spin and weave materials [12].

In Yunnan, rice cooked using bamboo is usually made by minority tribes. There is a story that people who went to farming or hunting in the mountains overcame the difficulty of making food by using bamboo as a place to cook. They put rice and water into the bamboo segments then burn it near the open fire until cooked [14].

The Deutero-Malay came to the Indonesian mainland after Proto-Malay between 300 and 200 BC [12] from South China, passed through Thailand and Malaysia, and then spread along the Indonesian coastal area [15]. The Deutero-Malay people already had a culture at the level of the metal age, when people were able to make equipment from iron [12].

The Proto-Malay and Deutero-Malay are groups of people who use Austronesian languages [10]. The tribes that exist in Indonesia today originate from one family, namely Malays, which are seen from their languages which are part of Malay-Polynesian or Austronesian language $[12,16]$. This race later became a native of Melaka Peninsula (Malay) and the islands of Southeast Asia [17].

Bakry, a culturalist of Minang, said that lemang was first known by the people of Minangkabau thanks to the teachings taught by ulama named Sheikh Burhanuddin according to the beliefs of the Minang people, especially the people in Pariaman, West Sumatra. In the past, Sheikh Burhanuddin often visited houses of people in Minangkabau to establish friendship and share the teachings of Islam. Although the teachings of Islam had developed in Minangkabau, Sheikh was still welcomed with food that was considered haram according to the teachings of Islam, such as pork curry, rat rendang, and fried snakes [11].

The habit of Minang people of using the same cooking tools to cook all kinds of food including haram food caused Sheikh Burhanuddin introduce a way to make lamang so the people would no longer use cooking utensils that had been used previously [18]. At that time, Sheikh Burhanuddin cooked rice in a bamboo segment that had not been touched by anyone. The bamboo was lined with banana leaves in order to prevent the rice from sticking to the bamboo. The bamboo that had been filled with rice was burned until cooked near the open fire made using firewood [11].

The process of cooking lamang was imitated by people who saw and listened to the explanation of Sheikh Burhanuddin [11]. According to Bakry, a culturalist, the attachment of the teachings of Sheikh Burhanuddin to the culture of the Minang people in carrying out Islamic religious activities caused the activities of making lamang which known as malamang become a habit that is done every several days before Islamic religious celebrations as well as other traditional events in Minangkabau. This tradition then continued to expand to other regions in Indonesia and abroad. This was presumably due to the nature of Minangkabau people who like to wander and trade [11]. 
However, the ancestors of Sheikh Burhanuddin are known to have originated from the Guguak Sikaladi located in Pariangan Subdistrict, Tanah Datar District, West Sumatra, which is the oldest and first country of Minangkabau people [19]. According to Graves (2007), the people of Minang were once a Deutero-Malay society who migrated from the mainland of South China to east of the island of Sumatra, along the Kampar river to darek (highlands) which became the home of Minangkabau people [20]. Therefore, it is assumed that Sheikh Burhanuddin already knew the method of cooking rice using bamboo because it was inherited from generation to generation by Deutero-Malay people who were the ancestors of the Minangkabau people.

\section{Tapai}

There is no information about how tapai (or tape) can be a companion menu for lemang. However, tapai itself was also allegedly found first by the Proto-Malay people. The word tapai originated from Proto-Malay-Polynesian "tapay" or Proto-Austronesian "tapal" which means "fermentation" [21].

As discussed earlier, the Proto-Malay people came from Yunnan Province, South China. The fermentation process itself is believed to be first discovered in China to preserve cereals and legumes [22]. The first discovery of alcoholic drinks made from rice, fruit, and honey is found in the village of Jiahu originating from the Neolithic era 7000-6600 BC [23].

Hesseltine (1983) reported that there was a food similar to tapai in China called lao chao. The process of making lao chao is the same as tapai, starting with soaking glutinous rice in water overnight and steaming it until soft. After the sticky rice being cooled at room temperature,
Chinese yeast powder is then added into the rice and the rice is fermented for 2 days. Just like tapai, lao chao is also semiliquid, tastes sweet and alcoholic [6].

\section{The philosophy of lamang and tapai in Minangkabau}

In Minangkabau, lamang (Fig. 2) is a food that must be present at certain times in West Sumatra, such as Eid (Eid al-Fitr and Eid al-Adha), commemoration of the Maulud Prophet, death anniversary, and baralek (wedding party). A few days before these times take place, people gather together to do malamang. There is also bulan lamang (few days before Ramadan), when people do malamang together [11].

There is no symbolic meaning behind the presentation of lamang and tapai in traditional ceremonies of Minangkabau people. However, some Minang people feel that lamang is incomplete if not consumed together with tapai in terms of taste. They likened lamang and tapai to a man and a woman. Man without woman or vice versa is considered imperfect like lamang without tapai [24].

On the other hand, Bakry also said that lamang itself symbolizes the closeness of the friendship relations of Minang people who complement each other. This can be seen from the rice grains which are sticking together and coconut milk as a complement in making lamang so the taste becomes savory. Moreover, malamang tradition itself, which is done together with lots of people, already shows the togetherness of the Minang people.

There are taboos that are believed by the people of Minang in making lamang and tapai which should not be violated. The bamboo that will be used to make lamang should not be stepped over because it is believed to cause lamang tajulua (rice coming out of bamboo when lamang is being

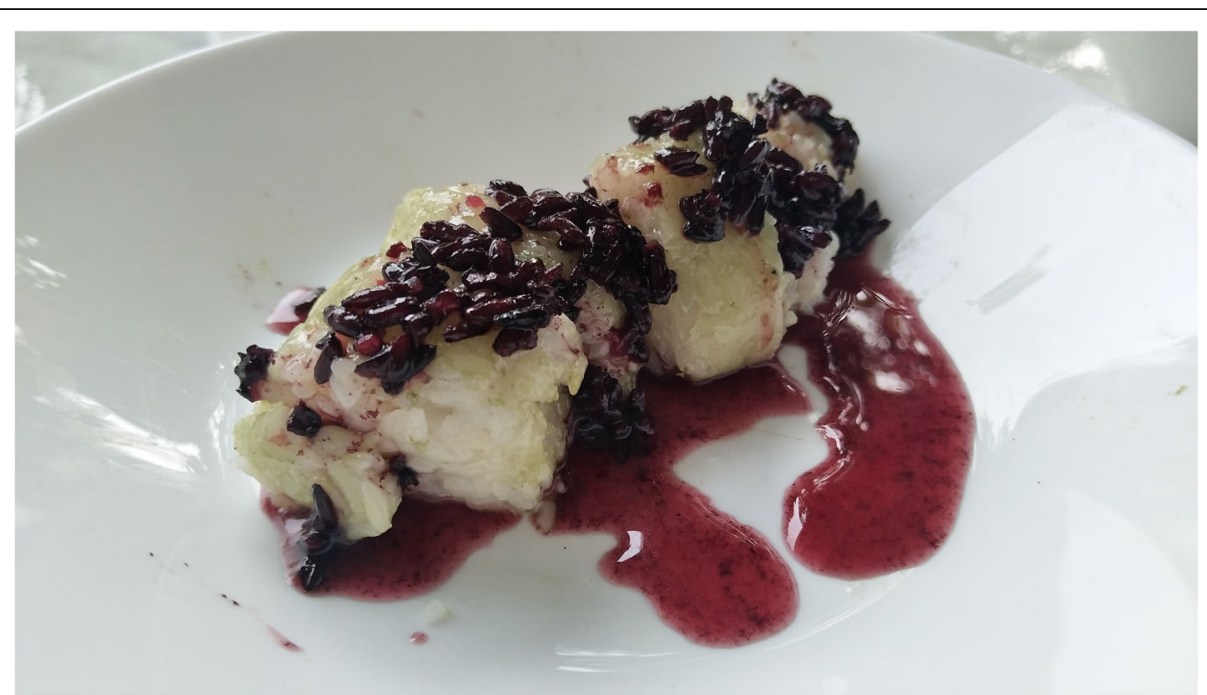

Fig. 2 Tapai poured on lemang. This kind of dish can be easily found in West Sumatra. Lemang is sometimes sold separately from tapai. Some people feel unsatisfied if lemang is consumed without tapai. Generally, people are excited to find this dish during the holy month of fasting 
cooked). Meanwhile, in making tapai, people who spread ragi to sticky rice must have done $w u d u$ (the procedure to clean ourselves by washing our face, hands, head, and feet with water) first and tapai should not be made by woman who is menstruating. Sticky rice is believed not to be fermented into tapai if these two things are violated [25].

There is also an allusion about lamang tapai that describes how a man and a woman should behave in a relationship. Lamang tapai which is usually made by Minang women should not have gravel. Gravel is believed to be a symbol of harm, because gravel in glutinous rice will hurt people if they are bitten when lamang and tapai are consumed [24].

The presence of gravels on lamang or tapai is likened to the destruction of life of a man and a woman because they engage in intercourse outside of marriage. Woman is usually more humiliated than man. They are no longer accepted in the community and are considered a disgrace in the family. The community usually will do eviction as a social sanction [24].

\section{Presentation of lamang tapai on traditional ceremonies in Minangkabau}

\section{Manjalang mintuo}

In the tradition of the Minangkabau people, lamang tapai was used as a gift from a daughter-in-law when visiting her in-laws [11] (Fig. 3). Lamang tapai is considered as a tool for a daughter-in-law to communicate about her household life to her in-laws. In-laws assess the harmony of the relationship between their son and daughter-in-law by tasting the taste of lamang and tapai given by the daughter-in-law [24].
The tradition of visiting in-laws and delivering food (usually includes lamang tapai) from the daughter-inlaw to the in-law or between families is usually done in the month of Ramadan. The tradition of delivering food to the in-laws is called pengantaran [26], and the tradition of visiting in-laws is called manjalang mintuo [27].

Asnan, a historian who is also a Minang people, also said that woman who brings lamang when visiting her parents-in-law will be more appreciated, because hard work and patience are needed in the process of making lamang which requires a long time and a lot of energy. However, based on Yulia (2010), newly married women now do not bother to make lamang tapai and prefer to bring ready-to-eat foods to the homes of their in-laws, while in-laws are also happier if they do not know the problems that affect the family of their son, especially the feelings of their daughter-in-law.

\section{Manjapuik marapulai}

Lamang tapai is also served at the manjapuik marapulai ceremony [25], the procession of picking up grooms to do the marriage agreement with the bride at the mosque or the bride's house and to be juxtaposed with the bride in a bridal bed at the bride's house. After marriage agreement in mosque, the bride and groom return to their own parents' homes even though they have legitimately become husband and wife $[28,29]$.

The man who had just gotten the status of a husband could only go to his wife's house after the wife's family group picked up the husband to be juxtaposed with his wife at her home according to the prevailing customs. The next day after marriage agreement event, ninik

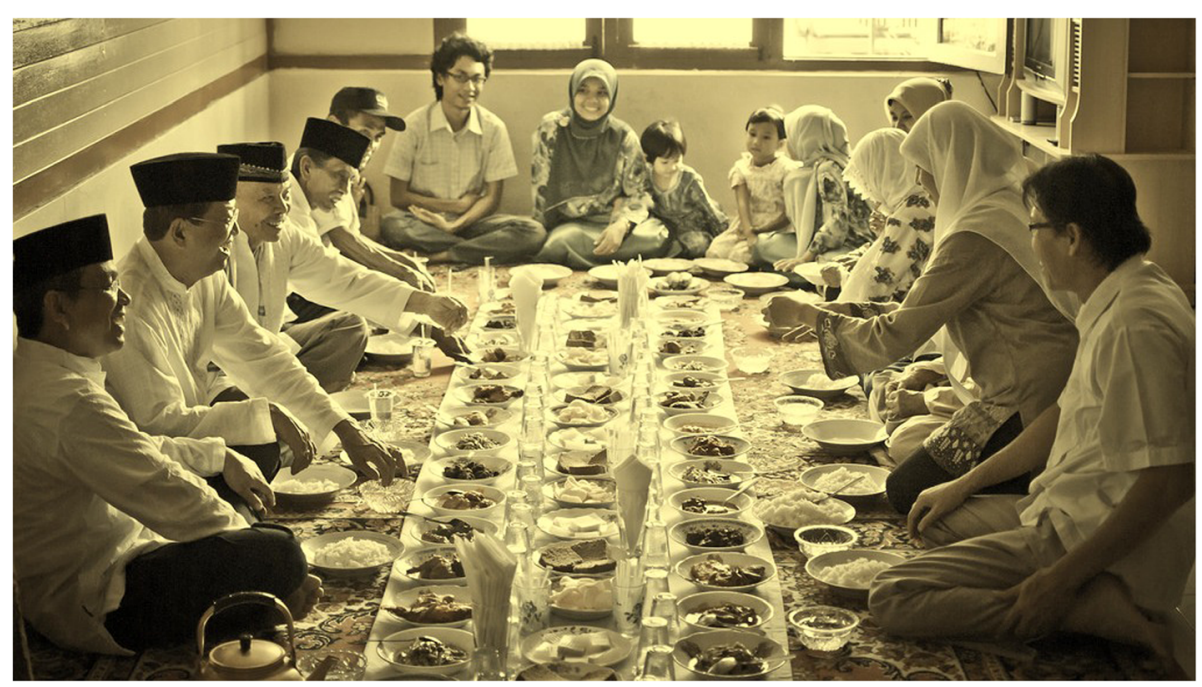

Fig. 3 Manjalang mintuo tradition in Minangkabau. A tradition which a daughter-in-law brings food to visit her in-laws. This event is held not long after the wedding ceremony and every Islamic holiday, such as Eid al-Fitr and Eid al-Adha. Such tradition is held to strengthen the relationship between in-laws and daughter-in-law. Lamang tapai becomes a food menu that must be carried on this tradition as a gift for in-laws. Source: marimembaca.com 
mamak (traditional ceremony leader), urang sumando (brother-in-law), and bundo kanduang (married woman) from the bride's family pick up marapulai (groom) to be juxtaposed on the bridal bed [28] (Fig. 4).

At this event, the family group of anak daro (the girl/bride) came to the house of marapulai and bring betel leaves and areca nuts in carano (ornamental and footed brass bowls, Fig. 5) as a sign of wellmannered presence (according to custom), complete groom outfit, yellow rice with singgang chicken, side dishes, cakes, and fruits [30]. For example, in Bayur village of Tanjung Raya Maninjau Regency, the family group of the bride brings jamba gadang (Fig. 6) to the family house of marapulai.

Every jamba gadang consists of one bowl of rice covered with leaves, then on top of it, there is a plate filled with lamang, galamai, and kalio meat which are also covered with leaves, then there are complementary foods such as pindang or pangek fish, one bowl of gulai cubadak, perkedel, pinyaram, sponge cake, and banana beside the rice bowl. Everything is arranged on a tray and covered with a serving hood and dulamak (cloth with gold embroidery) [28].

After sambah manyambah process (speech to convey the intention of the arrival of the bride's family) in the house of groom's family, all items brought by the bride's family were handed over to the groom's family and the groom is paraded to the house of the bride to be juxtaposed in the bridal bed [29]. After that, food and drinks will be served to the attendees. At that time, lamang and tapai will be served as a dessert [25].

\section{The flavor features of lemang and tapai from scientific perspective}

\section{Lemang}

Lemang has a pleasant aroma. There have been no studies of compounds that give aroma to lemang. However, the main ingredients of making lemang, such as bamboo, banana leaves, coconut milk, and sticky rice, are known to contain volatile compounds that contribute to producing a distinctive aroma of lemang.

\section{Bamboo of lemang}

The bamboo used to make lemang is Schizostachyum brachycladum [31]. Nineteen volatile compounds were found in S. brachycladum which are predominantly coumaran $(22.1 \%)$ and $\alpha$-elemol $(21.1 \%)$ of the total essential oils contained (4.9\%) [32].

\section{Banana leaves}

The leaf that is most often used as a wrapper for traditional Indonesian food is the leaf of the kluthuk banana plant or Musa balbisiana Colla. There have been no studies of volatile compounds contained in kluthuk banana leaves that are burned. However, 26 kinds of volatile compounds were found in this type of fresh banana leaf with 2,4-bis-(1,1-dimethylethyl)-

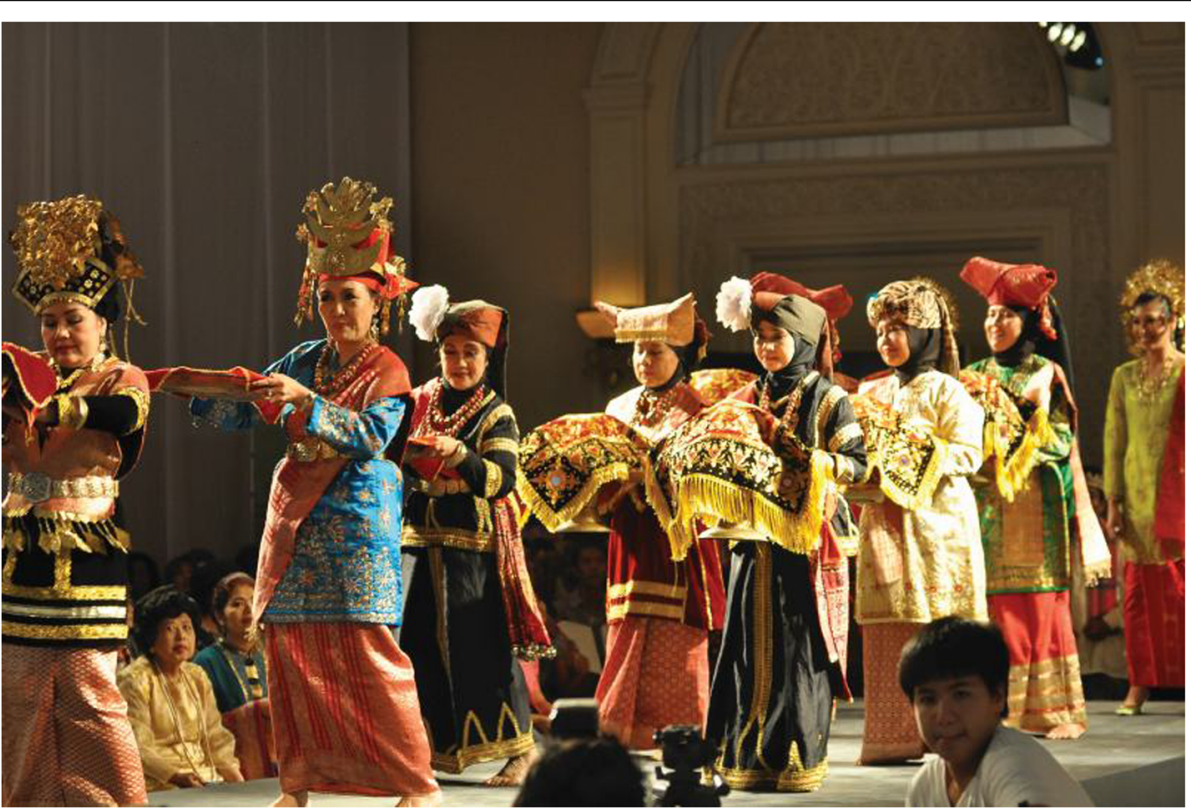

Fig. 4 An example of the manjapuik marapulai procession. The groom will be picked up by the family of the bride to be brought to the house of the anak daro (bride) to be juxtaposed in the bridal bed. This ceremony shows that the marriage proposal in Minang custom is done by the bride's family towards her husband candidate. In this procession, the family of the bride wore traditional clothes and brought important items to the groom's house. Important items are carried using carano and tray that are covered with special cloth. Source: mahligai-indonesia.com 


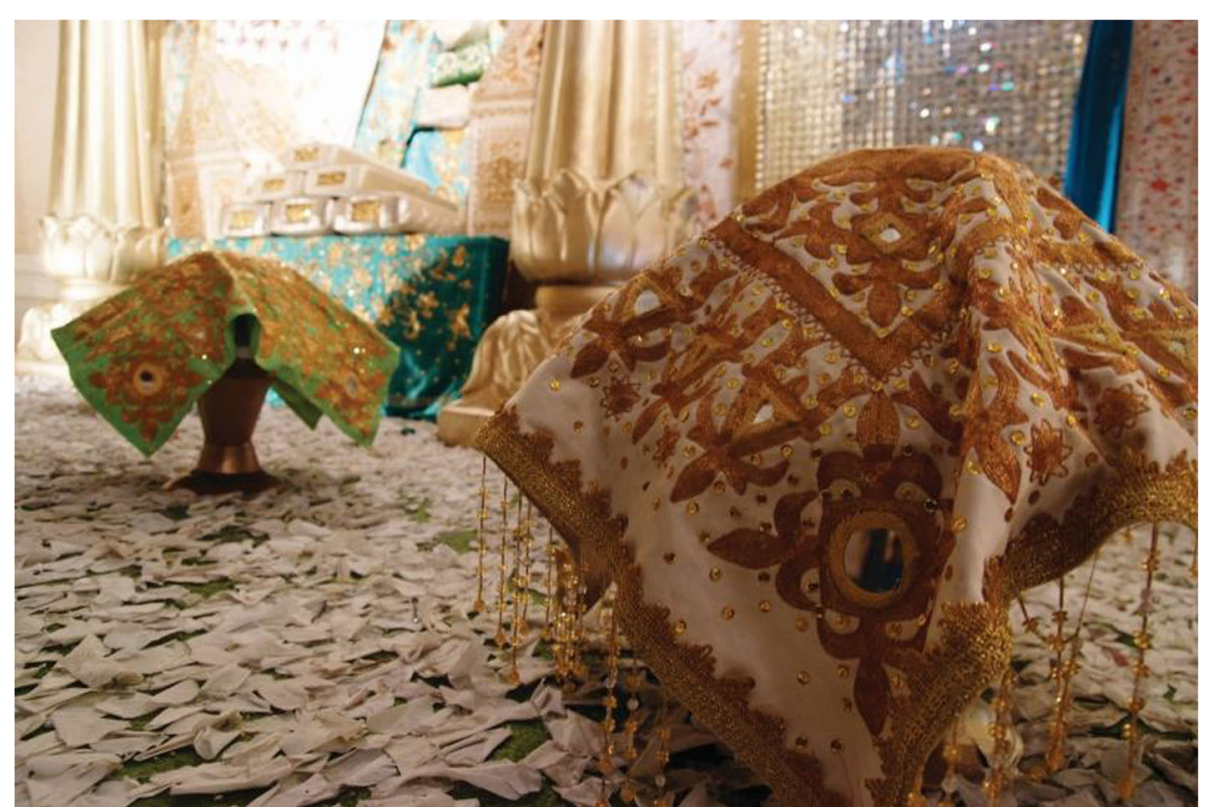

Fig. 5 Caranos to carry betel leaves and areca nuts which are covered with dulamak for the manjapuik marapulai ceremony. This vessel is made from brass metal. It is used as a marriage requirement. Bitter and sweet taste of betel leaf is a symbol of human hope and wisdom in responding their weaknesses. Weakness or irregularities that exist will not be gossip, while the sweet things in the meeting will be remembered forever. Source: mahligai-indonesia.com

phenol as the dominant compound. The number of volatile compounds in this type of banana leaf increased to 60 kinds after being steamed. The dominant volatile compound of the leaf after being steamed is tetradecan [33].

\section{Coconut milk}

Coconut milk is a thick white liquid extracted from old coconut meat. Traditionally, coconut milk is obtained by pressing the grated coconut meat with or without the addition of water [34]. The saturated fatty acid content of coconut milk is very high $(89-91 \%$ without the addition of water) [35], which cause lemang to be greasy. The distinctive aroma of coconut in coconut milk comes from 14 volatile compounds which are predominantly tetracontane and 2-hexanol [36].

\section{Glutinous rice (Oryza sativa var. glutinosa)}

White sticky rice which is the main ingredient of lemang itself also arouses aromas derived from 22 main volatile compounds which are predominantly hexanal [37]. The sticky texture of lemang is caused by the starch structure of glutinous rice. Starch consists of two fractions, namely amylose and amylopectin. The higher the amylopectin or the lower the amylose content in rice will make the rice texture stickier. Amylose content of glutinous rice is only $1-2 \%$, while rice in general which is found in ASEAN countries contains 13-25\% amylose [38].

\section{Tapai ketan}

Tapai ketan is famous for its sweet, sour, and alcoholic taste. Sweet taste of tapai comes from the addition of table sugar in the process of making tapai and simple sugar content which is the result of the saccharification process. Saccharification is the process of breaking complex sugars into simple molecular sugars by glucoamylase enzyme produced by amylolytic microorganisms such as Amylomyces rouxii, Endomycopsis burtonii, and Endomycopsis fibuligera found in ragi tape [7, 39-41].

On the other hand, the alcohol content in the tapai is the result of solving simple sugars with the zymase enzyme produced by Saccharomyces cerevisiae found in yeast [42]. According to Najib (2017), there are seven types of alcoholic compounds in tapai which are fermented using banana leaves as a container for 3 days [43]. The dominant alcohol compounds are ethanol and 3-methyl-1-butanol. Meanwhile, a little sour taste comes from lactic acid which is the result of lactic acid bacteria (BAL) fermenting simple sugars. Lactic acid bacteria found in ragi tape are Streptococcus faecalis, Lactobacillus plantarum, and Pediococcus pentosaceus [44, 45].

\section{Conclusion}

Lemang and tapai are thought to have been found since the Neolithic era by the Proto-Malay people. Lemang is often served at religious and traditional ceremonies of Minangkabau because it has become a habit of the 


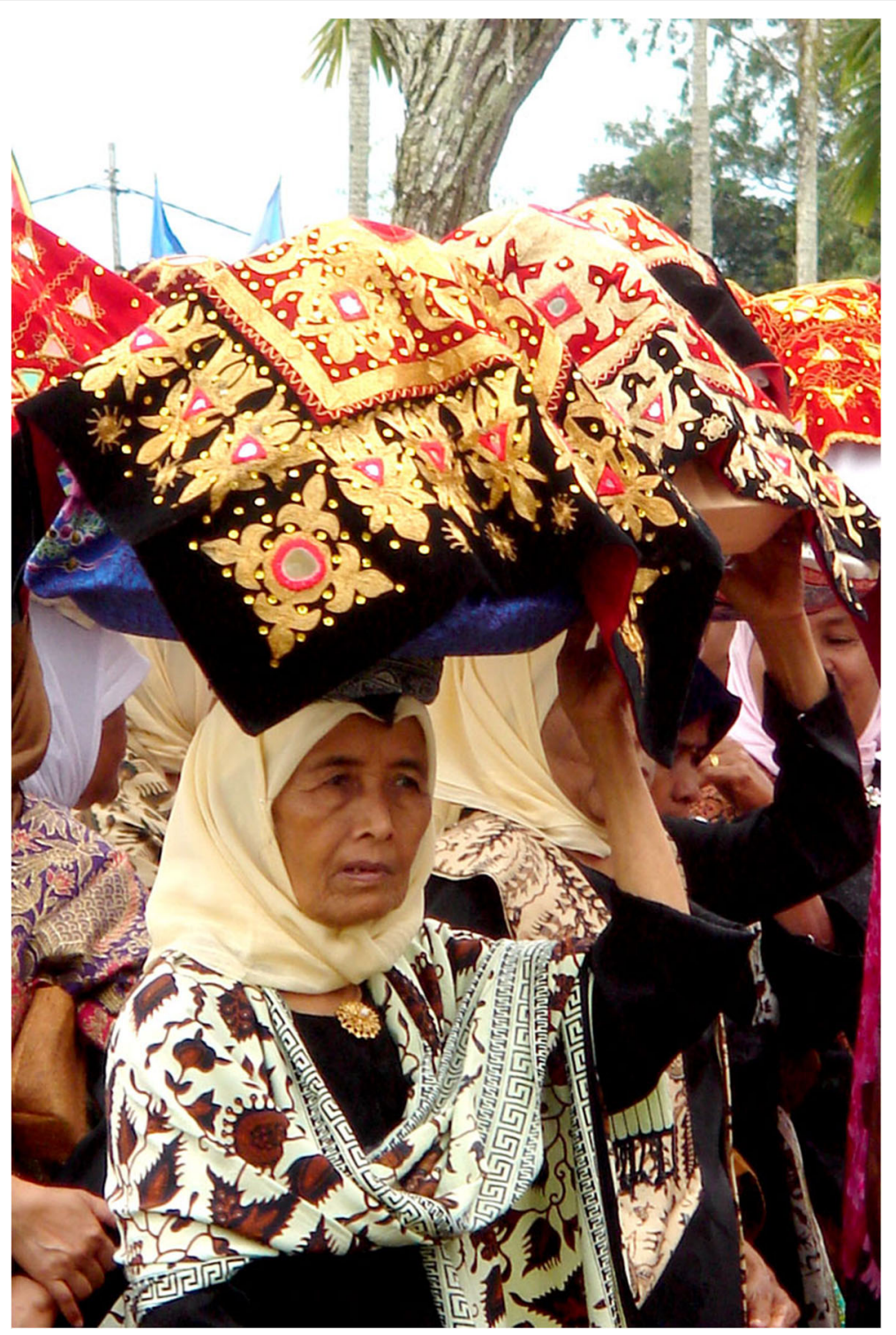

Fig. 6 Women carrying jamba on their head for makan bajamba event. Makan bajamba is the tradition of eating together on various traditional ceremonies and Islamic feast days. At the wedding ceremony, the family of the bride is the one who must bring this jamba to the groom's house. Jamba is a term for foods that is neatly arranged on a tray and covered with dulamak. Foods that must be brought are rice, lemang, meat, fish, cakes and fruit. Source: wikipedia.org

Minang people to serve it. The tradition of making lemang (malamang) itself is accustomed to being carried out every several days before the celebration of Islamic holidays because famous ulama named Sheikh Burhanuddin taught how to make lemang while visiting people's homes to teach Islam.

Some Minang people often feel lemang is incomplete if it is not eaten together with tapai, so both are considered as one food called lamang tapai. There are several taboos that must be obeyed in making lemang and tapai. Lemang and tapai are also used as gifts when visiting other people's homes, for example, when visiting in-laws or manjapuik marapulai ceremony. Lemang has a distinctive aroma derived from volatile compounds contained in its ingredients, while the sweet, sour, and bitter taste of tapai comes from the product of the breakdown of complex sugars from sticky rice by microorganisms found in yeast tape.

\section{Acknowledgements}

The author would like to express her sincere gratitude to all contributors who have shared the knowledge for the generation of this article. This sincere gratitude goes to Prof. Dr. Phil. Gusti Asnan, Professor of History at Andalas University of Padang, West Sumatra, Indonesia, and Dra. Hj. Sastri Yunizarti Bakry, the Minangkabau Culturalist. The author would also like to 
thank Dr. Albert Kuhon, food culture lecturer at Surya University, Tangerang Banten, Indonesia, who supported the creation of this article.

\section{Author's contributions}

The author read and approved the final manuscript.

\section{Funding}

Not applicable.

\section{Availability of data and materials}

Not applicable.

\section{Competing interests}

The author declares that there are no competing interests.

\section{Received: 16 July 2019 Accepted: 21 November 2019} Published online: 11 December 2019

\section{References}

1. Malay Mail. Continuing the legacy of cooking lemang for Hari Raya. 2017 [Accessed 20 April 2019]. Available at: https://www.malaymail.com/news/ eat-drink/2017/06/24/continuing-the-legacy-of-cooking-lemang-for-hariraya/1406545

2. Othman, A. Kudos to lemang griller. 2017 [Accessed 20 April 2019]. Available at: https://borneobulletin.com.bn/kudos-lemang-griller/

3. Phayomyong, M. Khao L. In: Saranukrom Wattanatham Thai Phak Nuea, Vol. 2. Bangkok, Thailand: Siam Commercial Bank Foundation for the Encyclopedia of Thai Culture, 1999; p. 828.

4. Wahyudi, et al. Lemang (rice bamboo) as a representative of typical Malay food in Indonesia. J Ethnic Foods. 2017;4(1):3-7.

5. Ardee. Cita rasa gurih dan legit dari lamang katan. 2019 [Accessed 12 July 2019]. Available at: https://www.indonesiakaya.com/jelajah-indonesia/detail/ citarasa-gurih-dan-legit-dari-lamang-katan

6. Hesseltine CW. Microbiology of oriental fermented foods. Ann Rev Microbiol. 1983;37(1):575-601.

7. Haard, et al. Cereal fermentations in countries of the Asia-Pacific region. In Fermented cereals: A global perspective. Rome, Italy: Food and Agriculture Organization of the United Nations; 1999.

8. Kementerian Pariwisata RI. Lemang tapai, penghangat tubuh di dataran tinggi Minangkabau. 2019 [Accessed 11 Nov 2019].

9. Rahim A. Jambi: Daerah rantau etnis Minangkabau. Jurnal IImiah Dikdaya. 2017;7(1):94-110.

10. Naim, M., Simulie, H. K. R. Dt. P., Moain, A. J., Zed, M., Nur, M. Menelusuri jejak Melayu-Minangkabau. Padang, Indonesia: Yayasan Citra Budaya Indonesia; 2002

11. Refisrul. Lamang dan tradisi malamang pada masyarakat Minangkabau. Jurnal Penelitian Sejarah dan Budaya. 2017;3(2):772-96.

12. Wojowasito S. Sedjarah kebudajaan Indonesia, Volume 2. Kalimosodo: Jakarta, Indonesia; 1960.

13. Yuming, Y., Kanglin, W., Shengji, P., Jiming, H. Bamboo diversity and traditional uses in Yunnan, China. Mountain Research and Development 2004; 24(2):157-165.

14. China Highlights. Rice cooked in bamboo tubes. 2018 [Accessed 21 Mei 2019]. Available at: https://www.chinahighlights.com/guilin/food/ricecooked-in-bamboo-tube.htm

15. Worosetyaningsih, T. Kehidupan masyarakat pada masa praaksara, masa Hindu, Budha, dan masa Islam. Ponorogo, Indonesia: Myria Publisher, 2019; p. 38.

16. Bellwood, P. Prehistory of the Indo-Malaysian Archipelago: Revised edition. Canberra, Australia: ANU E Press; 2007.

17. Simanjuntak, B. A. Melayu pesisir dan Batak pegunungan (orientasi nilai budaya). Jakarta, Indonesia: Yayasan Pustaka Obor Indonesia; 2010

18. Yunis M. Sistem kalender tradisional di Padang Pariaman. Polingua. 2017:1-24.

19. Toeah, H. D. Tambo alam Minangkabau. Bukittinggi, Indonesia: Pustaka Indonesia, 1976; p. 52

20. Graves, E. E. Asal-usul elite Minangkabau modern: respons terhadap colonial Belanda abad XIX/XX. Jakarta, Indonesia: Yayasan Obor Indonesia; 2007.

21. Fitrisia D, Widayati $D$. Changes in basic meanings from Proto-Austronesian to Acehnese. Studies in English Language and Education. 2018;5(1):114-25.
22. Vijayalakshmi, G., Lonsane, B. K., Krishnaiah, M. M. Yeast in food fermentations and therapeutics. In: F. T. Spencer, D. M. Spencer, eds., Yeasts in natural and artificial habitats. Berlin, Heidelberg, Germany: SpringerVerlag, 1997; 295-314

23. McGovern, et al. Fermented beverages of pre- and proto- historic China. Proc Natl Acad Sci. 2004;101(51):17593-8.

24. Yulia, N. "Kieh lamang tapai komunikasi simbolik di Minang". Media Indonesia, August 28, 2010. [Accessed 20 April 2019]. Available at: http://ftp. unpad.ac.id/koran/mediaindonesia/2010-08-28/mediaindonesia_2010-08-28_ 014.pdf

25. Kementerian Kebudayaan dan Pariwisata. Ensiklopedi makanan tradisional Indonesia (Sumatera). Jakarta, Indonesia: Kementerian Kebudayaan dan Pariwisata; 2004

26. Purwadi, D. Pengantaran, lamang tapai dari menantu untuk mertua. 2016 [Accessed 16 Mei 2019]. Available at: https://republika.co.id/berita/ ramadhan/tradisi-ramadhan/o7w0lh257/empengantaranem-lamang-tapaidari-menantu-untuk-mertua

27. Jensen, I. Tradisi manjalang mintuo jelang Ramadhan masih bertahan di Dharmasraya. 2019 [Accessed 16 Mei 2019]. Available at: https://sumbar. antaranews.com/berita/264547/tradisi-manjalang-mintuo-jelang-ramadhanmasih-bertahan-di-dharmasraya

28. Yorian, J. S., Elida E., Holinesti, R. Makanan adat pada acara manjapuik marapulai di Desa Bayur Kecamatan Tanjung Raya Maninjau. E-Journal Home Economic and Tourism 2016; 13 (3).

29. Tanjung S, Sinar TS, Nasution I, Takari M. The tradition of manjapuik marapulai in Minangkabau culture. KnE Social Sciences. 2018;3(4):878-90.

30. Putri, S. M. Perempuan dan modernitas: perubahan adat perkawinan Minangkabau pada awal abad ke-20. Yogyakarta, Indonesia: Gre Publishing; 2018

31. Nordahlia AS, Anwar UMK, Hamdan H, Latifl MA, Mahanim SMA. Anatomical, physical and strength properties of Schizostaschyum brachycladum (buluh lemang). Journal of Bamboo and Rattan 2011. 2011;10(3\&4):111-22.

32. Vairappan, C. S., Nagappan, T., Hui, L. T. Kulip, J. (2015). Chemical constituents and biological activities of essential oils from four species of bamboo genus Schizostachyum. J Trop Biol Conserv 2015; 12:127-136.

33. Fitriani, V. Identifikasi senyawa bioaktif dan karakterisasi fisik dan kimia daun pisang kluthuk (Musa balbisiana Colla) sebagai bahan pengemas pangan tradisional. Thesis. Yogyakarta, Indonesia: Universitas Gadjah Mada; 2016.

34. Ketaren, S. Minyak dan lemak pangan. Jakarta, Indonesia: UI-Press; 1986.

35. Hayati R. Profil asam lemak dan triasilgliserol berantai sedang (MCFA) dalam kelapa segar dan santan (Cocos nucifera L.). Agrista. 2010;14(3):82-6.

36. Kokilavani S. Sashidevi., Venilla, P., Kumar, R. A. Identification of volatile compound in coconut milk samples using GC-MS. Int J Curr Microbiol Appl Sci. 2017:6(11):1140-5.

37. Fukuda T, Takeda T, Yoshida S. Comparison of volatiles in cooked rice with various amylose contents. Food Sci Technol Res. 2014;20(6):1251-9.

38. Winarno, F. G. Kimia pangan dan gizi. Bogor, Indonesia: PT Embrio Biotekindo; 2018.

39. Ko SD. Tape fermentation. Appl Microbiol. 1972;23:976-8.

40. Kato K, Kuswanto K, Banno I, Harada T. Identification of Endomycopsis fibuligera isolated from ragi in Indonesia and properties of its crystalline glucoamylase. J Ferment Technol. 1976;54:831-7.

41. Cronk TC, Steinkraus KH, Hackler LR, Mattick LR. Indonesian tape ketan fermentation. Appl Environ Microbiol. 1977;33(5):1067-73.

42. Matz SA. Sereal Technology. Co. Inc. West Port, Connecticut: The Avi Publishing; 1970.

43. Najib, M. A. Sifat kimia dan profil senyawa volatile tape ketan yang dibungkus daun pisang (Musa sapientum var. Sylveteris) dan daun jambu air (Syzygium samarangense). Thesis. Yogyakarta, Indonesia: Universitas Gadjah Mada; 2017.

44. Ishimaru Y, Nakano M. Study on the microorganisms in the ragi. Rep Food Res Inst. 1960;18:158-63.

45. Soetarto, E.S.H., Takada, N. and Oshima, Y. Microflora in ragi and usar. Am. Rep. Int. Cent. Coop. Res. Dev. Microbiol. Eng. 1979; 1:211 225.

\section{Publisher's Note}

Springer Nature remains neutral with regard to jurisdictional claims in published maps and institutional affiliations. 